\title{
MENJADI PEWARTA TUHAN BERCERMIN DARI ST. PAULUS
}

\author{
Ignasius Suswakara, S.Fil M.Th
}

\section{Abstract:}

Paul becomes the evangelizer who is militant in their era. The changes of name from Saulus (Santo Paulus) turns to Paul becomes the starting point of the forming of a tought evangelizer in delivering the faith of Jesus. Paul and his persistency has succeeded to bring the God's words to go out from Jewish exclusifity and penetrates to the middle of other nations. That's why, Paul can be considered as the role model to the evangelizers who lived at this era. Paul become an excellent catechist, having strong personalities, and the manner can be used as the role model to the catechist today. A Paul's spirituality is the sample of a catechist excellent spirituality with good personality.

Keywords: evangelizer, Catechists, spirituality, Prophet (Paul).

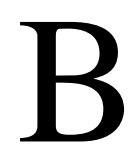

erbicara mengenai tokoh Kitab Suci yang berhasil dalam pewartaan, maka salah satu tokoh yang bisa dicontohi adalah Saulus atau Paulus. Paulus bukanlah tokoh baru dalam kehidupan orang Katolik. Ia sudah dikenal sebagai "Rasul bagi bangsa-bangsa". Tulisan ini berusaha mengangkat cerita mengenai pewartaaan Paulus dalam Kitab Suci yang dapat dijadikan refleksi bagi para ketekis di zaman sekarang.

Semuanya berawal dari peristiwa di Damsyik. Damsyik, kota ini selalu diingat oleh Paulus. Dalam perjalanan Paulus menuju Kota Damsyik untuk mengejar murid-murid Tuhan, ia mengalami penampakan Tuhan (Kis 9:1-19b). "Saulus, Saulus, mengapakah engkau menganiaya Aku?" Jawab Saulus: "Siapakah Engkau, Tuhan?” Kata-Nya: “Akulah Yesus yang kauaniaya itu”. Pengalaman pertemuan dengan Tuhan inilah yang akan mengubah seluruh hidup Paulus seterusnya. Paulus, sang penganiaya murid Tuhan menjadi rasul Tuhan yang paling berpengaruh. Orang yang sebelumnya menghadap Imam Besar, dan meminta surat kuasa dari padanya untuk dibawa kepada majelis-majelis Yahudi di Damsyik, supaya, jika ia menemukan laki-laki atau perempuan yang mengikuti Jalan Tuhan, ia menangkap mereka dan membawa mereka ke Yerusalem. Kini, telah menemukan makna hidupnya yang sesungguhnya yaitu menjadi hamba Tuhan. Suatu pertemuan yang akan membawa Paulus pada karya-karya ajaib Tuhan lainnya.

\section{Paulus Sang Pemuda Yahudi Yang Anti-Kristus}

Paulus dari Tarsus adalah seorang Yahudi. Tradisi seperti dikutip Hieronimus, mengatakan bahwa orang tuanya berasal dari Giskala, di Galilea (Brunot, 1973:14). Mereka termasuk suku Benyamin. Mereka bangga karena di zaman dahulu terpilih untuk menurunkan seorang raja bagi Israel, yaitu Raja Saul, raja orang Yahudi yang pertama. Nama Saul ini pulalah yang diberikan kepada anak ini pada hari sunatnya.

Paulus dilahirkan sebagai anak kota, bukan kota sembarangan kota melainkan kota yang besar dan bersemarak (Suharyo, 2008:5). Kota kelahirannya adalah Tarsus, yang adalah sebuah kota pelabuhan yang makmur di Cicilia (Turki sekarang) (Lukefahr, 2008: 221). Oleh karena itu, Tarsus menjadi kota pusat perdagangan. Di samping itu, Tarsus juga menjadi kota ilmu pengetahuan. Banyak orang pendatang yang belajar di sekolahsekolah terkenal di Tarsus, dan kemudian tersebar ke seluruh bagian kekaisaran Roma. Di kota ini tinggal orang-orang Yunani dan orang-orang Timur, juga bangsa-bangsa yang lain. Di kota Tarsus, Paulus mendapat 
kesempatan belajar tentang cara hidup bangsa yang bukan Yahudi. Oleh karena itu, ketika waktunya tiba, dia dapat memperkenalkan Injil Kristus kepada bangsa-bangsa lain dengan cara yang sangat baik.

Orangtua Paulus merupakan orang-orang Yahudi dan sekaligus menjadi warga negara Roma. Walaupun mereka berusaha melindungi Paulus dari pengaruh kafir sewaktu remaja, tetapi keadaan kota Tarsus membuat setiap anak yang cerdas terpengaruh oleh bahasa dan ide-ide kebudayaan Yunani yang kafir. Sewaktu masih sangat muda, orangtua Paulus memutuskan ia harus menjadi seorang rabi (guru hukum Taurat). Sebagai seorang anak kecil di Tarsus, ia belajar tentang tradisi-tradisi umat Yahudi melalui pendidikan yang teratur di sinagoge setempat. Alkitabnya yang pertama kemungkinan besar adalah Septuaginta, terjemahan Perjanjian Lama ke dalam bahasa Yunani (Brunot, 1973:17). Sewaktu tinggal di Tarsus, Paulus juga belajar membuat tenda, sebab setiap murid hukum Taurat dianjurkan mempelajari suatu ketrampilan di samping menuntut ilmu. Hal ini sangat bermanfaat bagi Paulus pada kemudian hari, sebab dengan demikian dia sanggup memperoleh nafkah sendiri Kemudian pada usia 13 sampai 15 tahun, ia dikirim ke Yerusalem untuk mendapatkan pendidikan yang lebih tinggi di sekolah kerabian (sebuah sekolah pendidikan dalam agama Yahudi).

Di sekolah ini Paulus memperoleh kesempatan untuk belajar di bawah bimbingan Gamaliel, salah seorang guru terbesar pada jaman itu. Paulus menjadi seorang murid yang istimewa dan rupanya Gamaliel memberikan penghargaan tinggi kepadanya. (Kis 22:3). Ketika Paulus telah menyelesaikan pendidikannya di Yerusalem, ia kembali ke kota aslinya, Tarsus. Sekarang dia sudah siap bekerja. Orangtua serta guru-gurunya sangat bangga kepadanya. Ada kemungkinan Paulus menghabiskan waktunya selama beberapa tahun di Tarsus sebagai seorang rabi, guru agama Yahudi. Tidak ada catatan lain tentang dia selama tahun-tahun itu sampai ia kemudian kembali ke Yerusalem, tepat sebelum kematian Stefanus, seorang pengikut Yesus Kristus.

Paulus sudah mendengar tentang gerakan Kristen yang menentang iman Yahudi. Paulus ingin pergi untuk membantu mempertahankan iman nenek moyangnya. Selama pengadilan Stefanus, Paulus ada di sana dengan teman-teman sebangsanya. Meskipun ia tidak ikut melempari Stefanus dengan batu, ia memiliki perasaan yang sama dengan orang-orang yang menganiaya Stefanus dan setuju bahwa Stefanus harus dihukum mati. Paulus menyaksikan kematian Stefanus. Walaupun ia tidak mengetahuinya pada waktu itu, kejadian ini memainkan peranan yang penting dalam keputusannya mengikut Tuhan Yesus Kristus di kemudian hari.

Paulus sendiri tidak pernah bisa melupakan apa yang pernah ia perbuat kepada orang-orang Yahudi, yang telah menerima ajaran Yesus (1 Korintus 15:9). Bahkan, ia sendiri menjuluki dirinya sebagai "penganiaya jemaat" (Filipi 3:6; Galatia 1:13) dan orang "yang paling berdosa" (1 Timotius 1:15), karena ia telah menganiaya Yesus dan para pengikut-Nya. Penganiayaan Saulus terhadap orang Kristen karena sebelumnya ia adalah seorang Yahudi yang sangat taat dan yang karena ketaatannya itu ia menganiaya jemaat Allah, sebab ia berpikir bahwa dengan melakukannya ia berbuat sesuatu yang benar menurut hukum taurat (Darmawijaya, 2006: 120). "Sebab kamu telah mendengar tentang hidupku dahulu dalam agama Yahudi: tanpa batas aku menganiaya jemaat Allah dan berusaha membinasakannya. Dan di dalam agama Yahudi aku jauh lebih maju dari banyak teman yang sebaya dengan aku di antara bangsaku, sebagai orang yang sangat rajin memelihara adat istiadat nenek moyangku" (Gal 1:13-14). "Karena aku adalah yang paling hina dari semua rasul, sebab aku telah menganiaya Jemaat Allah" (1Kor 15:9). "...aku yang tadinya seorang penghujat dan seorang penganiaya dan seorang ganas, tetapi aku telah dikasihani-Nya, karena semuanya itu telah kulakukan tanpa pengetahuan yaitu di luar iman" (1 Tim 1:13). ...”tentang pendirian terhadap hukum Taurat aku orang Farisi, tentang kegiatan aku penganiaya jemaat, tentang kebenaran dalam mentaati hukum Taurat aku tidak bercacat" (Flp 3:5 $6)$. 
Seseorang yang sedemikianlah yang kemudian dipanggil oleh Tuhan Yesus untuk menjadi Rasul-Nya, dan sungguh rahmat Tuhan-lah yang mengubahnya menjadi seorang Rasul yang luar biasa, yang dikenal dengan nama Rasul Paulus. Kasih Tuhan Yesus mengubah seluruh hidup Rasul Paulus, dan karena pengalaman dikasihi oleh Tuhan ini, Rasul Paulus dapat mengatakan ungkapan yang indah ini, yang juga dapat menjadi ungkapan hati semua yang mengimani Kristus: "namun aku hidup, tetapi bukan lagi aku sendiri yang hidup, melainkan Kristus yang hidup di dalam aku. Dan hidupku yang kuhidupi sekarang di dalam daging, adalah hidup oleh iman dalam Anak Allah yang telah mengasihi aku dan menyerahkan diri-Nya untuk aku." (Gal 2:20)

\section{Menjadi Katekis Dengan Seluruh Jiwa Raganya}

Perubahan dalam diri Paulus, tidak dengan sekaligus mengubah penilaian orang-orang terhadapnya baik itu orang Yahudi maupun jemaah Kristen awal terhadapnya. Jemaat Kristen awal masih mencurigainya sebagai penganiaya orang Kristen. Menghadapi situasi ini, selama tiga tahun ia pergi ke Arab (Nabatea, sebelah selatan Laut Merah) untuk berdoa dan merenung (Lukefahr, 2008:222). Mereka mencurigai dan menjauhi Paulus. Karena merasa tidak diterima oleh jemaat di Damsyik, Paulus pergi ke Arabia dan beberapa waktu kemudian dia kembali ke Damsyik (Gal 1:17). Sayangnya, usaha Paulus untuk melayani Tuhan di Damsyik belum juga berhasil. Pertobatannya yang sudah berjalan 1-2 tahun belum membuat masyarakat Yahudi yakin bahwa Paulus benar-benar sudah berubah. Mereka begitu jengkel dan berunding untuk membunuh Paulus (Kis 9:23). Untuk menyelamatkan diri, Paulus pergi ke Yerusalem. Nahasnya, di sana pun dia tidak mendapatkan perlakuan yang baik. Lagi-lagi, dia harus melarikan diri. Paulus pun pulang ke Tarsus sampai dengan Barnabas mengajaknya ke Antiokhia untuk perjalanan misi pertama mereka (Kis 9:26-30; Kis 11:22-26). Tahun-tahun pengasingan diri ini memberinya keyakinan yang matang dan kemampuan rohani yang ia butuhkan untuk pelayanan berikutnya. Kesetiaannya pada pewartaan mengenai Kristus muncul kembali dengan ajakan Barnabas. Ia pun memulai perjalanan panjang kemuridan yang penuh kisah dan drama. Umumnya perjalanan Paulus dibagi dalam tiga bagian: misi pertama, kedua, dan ketiga.

Perjalanan Misi Pertama. Misi pertama Paulus dilakukan bersama Barnabas ke daerah Antiokhia dan pulau Siprus. Di bawah kepemimpinan Barnabas, para jemaat di Antiokhia mampu bertumbuh dengan begitu pesatnya sehingga ia membutuhkan banyak bantuan. Ketika Paulus diminta datang dari Tarsus untuk membantu pekerjaan itu, jemaat menjadi makin lebih kuat lagi karena Paulus memiliki karunia untuk mengajar jemaat. Kemudian, para jemaat mulai memberikan perhatian kepada orang-orang yang bukan Yahudi yang ada di negara- negara lain. Para jemaat menyadari bahwa menyebarkan Injil kepada bangsa-bangsa lain adalah kewajiban mereka. Jemaat yang kuat ini memperoleh penghargaan dalam pelayanan mereka sebagai pusat penyebaran Injil kepada orang-orang yang bukan Yahudi. Di Antiokialah murid-murid ini pertama kali disebut Kristen (Kis 11:26). Ketika bencana kelaparan terjadi di Yudea, diduga sekitar tahun 45-46 atau 48 M, Paulus dan Barnabas berangkat ke Yerusalem untuk memberikan dukungan finansial dari komunitas Antiokhia. (Heuken, 1979: 244-246).

Sementara para penginjil ini sedang beristirahat dan bersekutu di Antiokia, mereka menerima kabar tentang adanya satu masalah besar, yang mengancam kehidupan jemaat itu sendiri. Pertanyaannya adalah dapatkah seorang bukan Yahudi menjadi seorang Kristen? Ketika Paulus mendengar hal ini, dengan segera ia melihat bahaya yang benar-benar mengancam jemaat. Masalah ini bisa memecah belah para jemaat, juga bisa menghambat pertumbuhan kekristenan itu sendiri. Paulus langsung mengambil sikap yang tegas atas masalah ini. Paulus mengatakan bahwa sunat tidak diperlukan supaya mereka dapat memperoleh keselamatan. Kemudian diputuskan untuk membawa masalah ini ke Yerusalem. Di Yerusalem, para pemimpin jemaat 
dipanggil bersama untuk pertemuan pribadi. Dalam pertemuan itu Petrus menceritakan kesaksiannya tentang seorang yang bukan Yahudi, yakni Kornelius. Paulus dan Barnabas juga membagikan berkat-berkat yang telah mereka terima pada saat mereka bersaksi kepada bangsa-bangsa lain. Keputusan akhir yang mereka ambil memberikan kemenangan yang melimpah bagi Paulus. Mereka memutuskan untuk mengirim sepucuk surat kepada seluruh jemaat dan menyatakan bahwa sunat dan upacara penerimaan secara Yahudi tidak dibutuhkan bagi orang yang bukan Yahudi yang ingin menjadi orang Kristen.

Perjalanan Misi Kedua. Dalam perjalanan misi kedua, setelah pertikaian dengan Barnabas karena persoalan Yohanes Markus, Paulus ditemani oleh Silas (Kis 15:36-41). Di sini terlihat pribadi Paulus yang tegas dan berprinsip. Ia tidak mau menyertakan Yohanes Markus, karena Yohanes Markus telah meninggalkan mereka saat perjalanan misi pertama mereka. Paulus dan Silas pun berangkat dari Antiokhia, menuju Siria dan Kilikia, dan tiba di selatan Galatia (Kis 16:1-20:38). Di Listra, Timotius bergabung dengan mereka. Mereka menyeberangi daerah Frigia dan perbatasan Misia. Lalu mereka bergabung dengan Lukas di Troas. Dia memutuskan untuk pergi ke Eropa, dan di Makedonia ia mendirikan komunitas Kristen pertama Eropa: Jemaat Filipi. Juga di Tesalonika, Berea, Atena dan Korintus. Dia tinggal selama 1,5 tahun di Korintus, di rumah sepasang suami-isteri, Akwila dan Priskila (Kis 18:11). Masa tinggalnya ini bersamaan dengan waktu Galio menjabat singkat sebagai gubernur (prokonsul) di Akhaya dari 1 Juli 51 sampai 1 Juli 52. Pada musim dingin tahun 51, ia menulis surat pertama kepada Jemaat Tesalonika, dokumen tertua dari Perjanjian Baru. Tahun berikutnya ia kembali ke Antiokhia.

Perjalanan Misi Ketiga. Setelah tinggal di Antiokhia beberapa saat, Paulus pergi ke Galatia dan Frigia untuk mendukung gereja-gereja yang telah ia dirikan pada perjalanan sebelumnya (Kis 18:23). Kemudian ia berkeliling pada wilayah barat Bitinia dan tiba di Efesus dengan perjalanan darat. Di Efesus ia menulis surat pertamanya kepada orang-orang Korintus pada tahun 54 dan surat kedua pada akhir 57. Setelah tiga tahun di Efesus, Paulus kemudian mengunjungi Asia Kecil dan Yunani. Kemudian mendahului Lukas, ia berlayar ke Troas, disertai beberapa murid-muridnya (Kis 20:4), disebabkan karena rencana pembunuhan terhadap dirinya oleh orang-orang Yahudi. Dan akhirnya ia kembali ke Yerusalem dan bertemu dengan Yakobus di sana.

\section{Penangkapan}

Paulus tiba di Yerusalem tahun 57 membawa uang sumbangan yang dikumpulkan untuk jemaat di sana dari kota-kota yang dikunjunginya. Ia disambung hangat, tetapi juga ditanya dengan teliti oleh Yakobus mengenai tuduhan bahwa ia "mengajar semua orang Yahudi yang tinggal di antara bangsa-bangsa lain untuk melepaskan hukum Musa, sebab engkau mengatakan, supaya mereka jangan menyunatkan anak-anaknya dan jangan hidup menurut adat istiadat" Yahudi. Paulus dianjurkan untuk melakukan upacara pentahiran, supaya "semua orang akan tahu, bahwa segala kabar yang mereka dengar tentang engkau sama sekali tidak benar, melainkan bahwa engkau tetap memelihara hukum Taurat" (Kis 21:1-26),

Tidak berapa lama setelah sampai di Yerusalem, Paulus ditangkap dengan tuduhan membawa orang-orang bukan Yahudi ke dalam Bait Allah (Kis 21:27-36). Paulus dibawa ke markas tentara Romawi dan dihadapkan kepada Gubernur Romawi Antonius Feliks di Kaisarea (Kis 23:12-35). Ia ditahan selama 2 tahun, sampai gubernur yang baru, Perkius Festus, membuka kembali kasusnya pada tahun 59. Karena tidak mau diadili di Yerusalem, Paulus menyatakan banding kepada Kaisar, sehingga kemudian ia dikirim ke Roma dengan naik kapal (Kis 27:1-44). 


\section{Spiritulitas Katekis}

Dalam cerita-cerita mengenai Paulus dalam Kitab Suci, ada beberapa hal yang dapat dipetik dalam hubungannya dengan spiritualitas seorang Katekis.

Kebersatuan dalam Allah.

Pengalaman pertobatan dan kebersamaan dengan Allah menjadikan Paulus selalu mengandalkan Kristus dalam setiap karya pewartaannya. Kebersamaan dengan Tuhan inilah yang membuat ia tetap setia menjadi pewarta Sabda Tuhan sekalipun sering dikejar, dipenjara, difitnah, rela tidak beristirahat berhari-hari demi perkembangan pewartaan Karya Kristus. Pemahaman Paulus yang sangat khas mengenai iman Kristiani membawa ia pada pertentangan yang sangat hebat dalam karyanya, baik dalam teologinya, maupun dalam karya kerasulannya yang konkrit pastoral (Jacobs, 1993: 23). Sekalipun demikian imannya tidak goyah. Ia telah menjadi "hamba Kristus Yesus" (Roma 1:1; Galatia 1:1).

Mewartakan dalam kebersamaan dengan yang lain.

Kehadiran Ananias sebagai murid Tuhan yang telah menyembuhkannya membuat keyakinannya semakin kuat bahwa Kristus hadir dalam diri rekan-rekan seiman. Pengaruh Barnabas terhadap dirinya juga mampu mengangkat dia dari frustrasi karena penolakan orang-orang Yahudi terhadap pewartaannya. Dan kebersamaan itu, Paulus tunjukkan seterusnya dalam karya misinya. Ia selalu bersama orang lain dalam menjalankan misi pewartaan. Misi pertama Paulus jalani bersama Barnabas dan Yohanes Markus (Kis 13:4-13). Perjalanan kedua dan ketiga ia lakukan bersama Silas, Timotius dan Lukas.

Kebersatuan dengan para rasul lainnya.

Dalam perjalanan pewartaan injil, Paulus memikirkan hubungan antara orang-orang non-Yahudi yang telah bertobat dengan kalangan orang Yahudi Kristen. Meskipun telah bertobat, orang-orang percaya nonYahudi ini tetap dianggap kelas "dua", sehingga menghalangi mereka untuk menjadi "anggota penuh" jemaat Yahudi. Paulus bersama Barnabas pergi ke Yerusalem untuk membicarakan masalah ini dengan para pemimpin Gereja di sana. Paulus berhasil memikat hati banyak orang dengan pemaparan pandangannya mengenai masalah tersebut. Konsili ini menghasilkan beberapa keputusan penting, misalnya:

untuk menikmati karya penyelamatan Yesus, orang tidak harus menjadi Yahudi terlebih dahulu

orang-orang Kristen yang bukan berasal dari latar belakang Yahudi tidak diwajibkan mengikuti tradisi dan pantangan Yahudi (misalnya perihal tentang sunat dan memakan makanan yang diharamkan).

Paulus mendapat mandat untuk memberitakan Injil ke daerah-daerah berbahasa Yunani.

Kebersatuan dengan komunitas Gereja lainnya nampak saat bencana kelaparan terjadi di Yudea, diduga sekitar tahun 45-46 atau $48 \mathrm{M}$, Paulus dan Barnabas berangkat ke Yerusalem untuk memberikan dukungan finansial dari komunitas Antiokhia. Kisah singkat ini menunjukkan bagaimana kegiatan jemaat menjalin hubungan dengan jemaat induk di Yerusalem (Darmawijaya, 2006:148)

Berbeda pendapat namun tetap satu dalam karya pewartaan.

Pertemuan di Yerusalem telah membawa perubahan besar dalam karya pewartaan Kristus selanjutnya. Sayangnya, di sana terjadi dua peristiwa yang meretakkan hubungan kerja Paulus dengan Barnabas dan Petrus. Awalnya, Petrus mendukung pandangan Paulus untuk membebaskan orang bukan Yahudi dari 
aturan makan orang Yahudi, bahkan memberikan teladan dengan cara makan bersama-sama orang nonYahudi. Namun, selanjutnya Petrus mengundurkan diri dan menjauhi mereka (Galatia 2:12). Barnabas pun turut terseret dengan Petrus. Inilah peristiwa pertama yang meretakkan hubungan mereka. Peristiwa kedua adalah Paulus menentang Barnabas untuk membawa serta Yohanes Markus dalam perjalanan penginjilan mereka. Hal ini menimbulkan perselisihan yang tajam (Kis 15:39). Alhasil, mereka selanjutnya mengambil rute yang berbeda dalam perjalanan penginjilan. Namun, hal ini justru membuat Injil tersebar lebih luas. Walau mereka berbeda pendapat, namun karya pewartaan tetap berjalan, warta Injil tetap berkumandang mengajak orang untuk takwa kepada Allah yang menciptakan langit dan bumi (Kis 14-15).

Kepribadian yang rendah hati, berani dan mandiri.

Sebagai seorang murid Tuhan, Paulus selalu berani menilai dirinya, baik itu kelemahan maupun kelebihannya (Suharyo, 2008: 32). Ia juga tidak mencari pujian atas semua hal yang telah dilakukannya. Dalam 1 Tesalonika 2:5-6, ia menulis: 'Karena kami tidak pernah bermulut manis -- hal itu kamu ketahui -- dan tidak pernah mempunyai maksud loba yang tersembunyi -- Allah adalah saksi --juga tidak pernah kami mencari pujian dari manusia, baik dari kamu, maupun dari orang-orang lain, sekalipun kami dapat berbuat demikian sebagai rasul-rasul Kristus. Dalam pemakluman injil, Paulus telah melayani Tuhan dengan semangat rendah hati, sambil mencucurkan air mata, dan menghadapi pelbagai pencobaan (Kis 20:19). Biasanya orang yang rendah hati cenderung untuk diam, tidak mau banyak bicara. Tetapi bagi Paulus, bersikap rendah hati tidak berarti bersifat penakut. Sikap rendah hati Paulus bertumbuh sejalan dengan semangat dan keberanian untuk mengkotbahkan Sabda Allah di tengah tantangan entah pada waktu yang berkenan maupun yang tidak berkenan. Paulus memiliki keberanian dalam berbicara untuk merebut hati orang dan menghantar mereka kepada Tuhan (Hayon, 1989:126).

Sewaktu tinggal di Tarsus, Paulus juga belajar membuat tenda, sebab setiap murid Hukum Taurat dianjurkan mempelajari suatu ketrampilan di samping menuntut ilmu. Hal ini sangat bermanfaat bagi Paulus pada kemudian hari, sebab dengan demikian dia sanggup memperoleh nafkah sendiri sewaktu melakukan pekerjaan misionernya. Sesuai dengan kebiasaan Yahudi ia belajar mengerjakan salah satu pekerjaan tangan (ia adalah seorang pembuat kemah; Kis 18:3) yang dilakukannya di tengah-tengah kesibukan karya kerasulannya, dan dipakainya untuk penghidupan (Kis 18:3; 1Kor 4:12; 1Tes 2:9) sehingga ia tidak tergantung pada siapapun juga (1Kor 9:15).

Kepemimpinan Partisipatif

Dalam perjalanan misi, Paulus dan Barnabas selalu mengumpulkan mereka yang percaya kepada Kristus dalam kelompok jemaat. Ketika meninggalkan sebuah kota atau daerah, mereka tidak meninggalkan umat begitu saja. Paulus dan Barnabas akan memilih penatua yang dapat bertanggung jawab untuk jemaat-jemaat ini. Penatua ini yang akan berlaku sebagai pemimpin, sebagai gembala dan guru. Surat-surat Paulus menjadi alat komunikasi antara dirinya dengan komunitas-komunitas Kristen perdana yang telah dibentuknya.

\section{DAFTAR PUSTAKA}

Brunot, Amedee. 1973. Paulus, Yogyakarta: Penerbit Kanisius. 
Drane, John. 1996. Memahami Perjanjian Baru. Jakarta: BPK Gunung Mulia.

Jacobs, T. 1993. Paulus: Hidup Karya dan Teologinya, Yogyakarta: Kanisius.

Hayon, Nikolaus (Editor). 1989. Tema-tema Paulus, Ende: Penerbit Nusa Indah.

Heuken, A. 1979. Ensiklopedi Orang Kudus. Jakarta: Yayasan Cipta Loka Caraka

Lembaga Biblika Indonesia, 1981. Surat-Surat Paulus I, Yogyakarta: Kanisius.

Lukefahr, Oscar. 2008. A Catholic Guide To The Bible. Jakarta: Obor.

St. Darmawijaya. 1992. Sekilas Bersama Paulus, Yogyakarta: Kanisius.

St. Darmawijaya, 2006. Kisah Para Rasul, Yogyakarta: Kanisius.

Suharyo, I. 2008. Paulus Rasul Bangsa-Bangsa, Jakarta: Lembaga Biblika Indonesia. 1991. Mengenal Tulisan Perjanjian Baru, Yogyakarta: Kanisius. 